\title{
PERSEPSI NELAYAN TERHADAP PENGGUNAAN LPG SEBAGAI BAHAN BAKAR PADA MESIN PERAHU DI KABUPATEN SUKABUMI
}

\author{
Fishers Perception to Aplication about LPG as Fuel in Boat Machines in Sukabumi Regency
}

Oleh:

Johan Wahyudi 1*, Mohammad Imron², Wazir Mawardi²

${ }^{1}$ Dinas Kelautan dan Perikanan Kabupaten Sukabumi

${ }^{2}$ Program Studi Teknologi Perikanan Laut, FPIK IPB

*Korespondensi : joo.wahyudi060682@gmail.com

\begin{abstract}
ABSTRAK
Kebijakan diversifikasi energi pada bidang perikanan diharapkan nelayan dapat beralih dari bahan bakar minyak ke bahan bakar gas, namun pada kenyataannya nelayan masih menggunakan BBM sebagai bahan bakar untuk mesin perahunya Penelitian bertujuan untuk mengidentifikasi karakteristik sosial-ekonomi dan menilai persepsi nelayan terhadap penggunaan LPG sebagai bahan bakar pada mesin perahu di Kabupaten Sukabumi. Metode survey digunakan untuk mewawancarai sebanyak 94 orang responden. Hasil penelitian menunjukan bahwa sebagian besar nelayan di Kabupaten Sukabumi tergolong kelas umur yang masih produktif, memiliki pengalaman yang relatif lama, memiliki antusiasme yang tinggi terhadap informasi. Namum, tingkat pendidikan nelayan masih rendah dan pendapatan nelayan yang masih berada dibawah upah minimum kabupaten. Persepsi nelayan terhadap penggunaan LPG sebagai bahan bakar pada mesin perahu secara umum memiliki nilai rata-rata sebesar 53.19\% termasuk kategori sedang.
\end{abstract}

Kata kunci : karakteristik sosial-ekonomi, LPG, persepsi nelayan.

\begin{abstract}
Energy diversification policy in the fisheries sector is expected that fisher's can switch from fuel oil to $L P G$, but in fact he still use BBM as fuel for their boat engines. The objactive of this research was to identify socio-economic character and assess fisher's perceptions of the aplication of LPG as fuel on boat engines in Sukabumi Regency. The survey method was used to interview 94 respondents. The results showed that fishermen in Sukabumi Regency were mostly in the productive age range, have a long experience on fishing, and have a high enthusiasm for information. However, the education level of fishermen is still low and have an income below average the regency minimum wage. Fisher's perception of the use of LPG on boat engines in general has an average value of $53.19 \%$ including the medium category.
\end{abstract}

Keywords: fisher's perception, LPG, socio-economic character.

\section{PENDAHULUAN}

Agenda penting pemerintah dalam usahanya untuk meminimalkan kebutuhan akan sumber energi dari bahan bakar minyak (BBM) adalah dengan mendorong adanya penggunaan sumber-sumber energi alternatif (Mulyatno et al. 2013). Menurut Nono et al (2017) dikarenakan tidak tersedianya cadangan minyak di alam dalam jumlah besar untuk jangka waktu panjang, memaksa para pemangku kepentingan agar mengantisipasi hal tersebut. Kebijakan diversifikasi energi pada bidang perikanan berupa penyediaan dan pendistribusian Liquefied Petroleum Gas untuk kapal perikanan skala kecil merupakan salah satu upaya pemerintah yang tertuang dalam Peraturan Presiden Republik Indonesia 
nomor 126 Tahun 2015 tentang penyediaan, pendistribusian dan penetapan harga LPG untuk kapal perikanan bagi nelayan kecil.

Kebijakan tersebut dilaksanakan melalui program konversi BBM ke LPG yang diawali dengan memberikan bantuan berupa konverter kit (alat pengubah BBM ke BBG) beserta mesinnya dan tabung LPG $3 \mathrm{Kg}$ sebanyak dua buah kepada nelayan (KESDM 2017). Daerah di Indonesia yang menjadi target sasaran program konversi BBM ke BBG bagi nelayan pada tahun 2016 sebanyak 10 lokasi dengan jumlah 5.473 unit dan pada tahun 2017 sebanyak 28 lokasi dengan jumlah 17.081 paket (KESDM 2018). Salah satu daerah di Jawa Barat yang mendapatkan paket konventer kit bagi nelayan adalah Kabupaten Sukabumi yaitu sebanyak 1424 unit, Paket tersebut tersebar di 9 Kecamatan pesisir Kabupaten Sukabumi (DKP Kabupaten Sukabumi 2018).

Pemerintah berharap dengan adanya bantuan konverter kit bagi nelayan dari program konversi BBM ke BBG bisa menjadi solusi dalam mengatasi kelangkaan BBM dengan menyediakan bahan bakar alternatif yaitu penggunaan LPG sebagai bahan bakar mesin perahu dan membantu ekonomi masyarakat nelayan menjadi sejahtera (Wibowo 2016). Pada kenyataannya di lapangan, penggunaan BBG sebagai bahan bakar alternatif masih belum banyak digunakan oleh nelayan (Kuncoro et al. 2016). Berdasarkan pengamatan awal di lapangan dengan beberapa nelayan penerima paket konverter kit pada bulan Agustus 2018, sebagian besar nelayan penerima paket konventer kit di Kabupaten Sukabumi enggan menggunakan LPG, nelayan masih menggunakan BBM sebagai bahan bakar untuk mesin perahunya.

Evaluasi terhadap respon nelayan berdasarkan penjelasan sebelumnya sangatlah diperlukan. Nelayan merupakan target sasaran yang berperan penting dalam implementasi program konversi BBM ke BBG bagi nelayan. Penerimaan nelayan yang baik terhadap program Konversi BBM ke BBG khususnya penggunaan LPG sebagai bahan bakar pada mesin perahu akan membawa dampak baik bagi suksesnya program tersebut, dan juga sebaliknya. Evaluasi dapat dilakukan melalui pengukuran pemahaman atau persepsi nelayan terhadap penggunaan LPG sebagai bahan bakar pada mesin perahu.

Berdasarkan permasalahan tersebut maka perlu dilakukan penilaian persepsi nelayan terhadap penggunaan LPG sebagai bahan bakar pada mesin perahu dengan mengidentifikasi aspek sosialekonomi yang mempengaruhinya. Melakukan pengkajian mengenai persepsi seseorang, maka tidak boleh dipisahkan dari karakteristik sosial-ekonominya (Nababan 2017).

Penelitian ini bertujuan untuk mengidentifikasi karakteristik sosial-ekonomi nelayan dan menilai tingkat persepsi masyarakat nelayan terhadap penggunaan LPG sebagai bahan bakar pada mesin perahu di Kabupaten Sukabumi.

\section{METODE PENELITIAN}

Penelitian dilakukan di 9 (sembilan) Kecamatan pesisir di Kabupaten Sukabumi pada bulan April 2019 sampai Juni 2019. Metode penelitian menggunakan metode survei. Metode survei dilakukan terhadap suatu populasi dengan cara mengambil atau mempelajari sebagian data dari populasi tersebut (Sugiyono 2013). Data penelitian dikumpulkan dengan melakukan wawancara kepada 94 nelayan penerima bantuan paket konverter kit dari populasi sebanyak 1424 nelayan. Data yang dikumpulkan adalah data karakteristik sosial-ekonomi dan persepsi nelayan terhadap penggunaan LPG sebagai bahan bakar pada mesin perahu. Data karakteristik sosial-ekonomi meliputi umur, pendidikan, pengalaman menjadi nelayan, pernah/tidaknya mengikuti sosialisasi mengenai perikanan dan pendapatan nelayan. Adapun jenis dan cara pengumpulan data karakteristik sosial-ekonomi dapat dilihat pada Tabel 1. 
Tabel 1 Karakteristik sosial-ekonomi nelayan

\begin{tabular}{|c|c|c|c|c|}
\hline No & Jenis data & Kelompok data & Sumber data & $\begin{array}{c}\text { Cara pengumpulan } \\
\text { data }\end{array}$ \\
\hline 1. & Umur & $\begin{array}{l}\text { Klasifikasi Depkes RI tahun } 2009 \\
\text { : } \\
\text { a. Remaja : } 12-25 \text { tahun } \\
\text { b. Dewasa: } 26-45 \text { tahun } \\
\text { c. Lansia : } 46-65 \text { tahun } \\
\text { d. Manula : }>65 \text { tahun }\end{array}$ & $\begin{array}{c}\text { Nelayan } \\
\text { penerima paket } \\
\text { konverter kit }\end{array}$ & wawancara \\
\hline 2. & Pendidikan & $\begin{array}{l}\text { Undang-Undang Nomor } 20 \\
\text { Tahun 2003: } \\
\text { a. Tidak Lulus SD } \\
\text { b. Lulus SD } \\
\text { c. Lulus SMP } \\
\text { d. Lulus SMA }\end{array}$ & $\begin{array}{c}\text { Nelayan } \\
\text { penerima paket } \\
\text { konverter kit }\end{array}$ & wawancara \\
\hline 3. & $\begin{array}{l}\text { Pengalaman } \\
\text { Menjadi } \\
\text { nelayan }\end{array}$ & $\begin{array}{l}\text { a. } 0-12,5 \text { tahun } \\
\text { b. } 2.6-25 \text { tahun } \\
\text { c. } 25,1-37.5 \text { tahun } \\
\text { d. } 37.6-50 \text { tahun } \\
\end{array}$ & $\begin{array}{c}\text { Nelayan } \\
\text { penerima paket } \\
\text { konverter kit }\end{array}$ & wawancara \\
\hline 4. & Sosialisasi & $\begin{array}{ll}\text { a. Tidak pernah } \\
\text { b. pernah }\end{array}$ & $\begin{array}{c}\text { Nelayan } \\
\text { penerima paket } \\
\text { konverter kit }\end{array}$ & wawancara \\
\hline 5. & Pendapatan & $\begin{array}{l}\text { berdasarkan UMK Kabupaten } \\
\text { Sukabumi tahun } 2018 \text { : } \\
\text { a. di bawah UMK }(<2.583 \text { juta }) \\
\text { b. di atas UMK ( }>2.583 \text { juta })\end{array}$ & $\begin{array}{c}\text { Nelayan } \\
\text { penerima paket } \\
\text { konverter kit }\end{array}$ & wawancara \\
\hline
\end{tabular}

Data yang dikumpulkan untuk menilai persepsi nelayan terhadap penggunaan LPG sebagai bahan bakar pada mesin perahu meliputi ketersediaan, lokasi perolehan LPG, harga, laju konsumsi bahan bakar LPG, biaya operasional, luasan area kerja di perahu, faktor keamanan dan keselamatan, kemudahan pemasangan instalasi konverter kit, kecepatan dan sosialisasi. Adapun jenis dan cara pengumpulan data persepsi nelayan terhadap penggunaan bahan bakar LPG pada mesin perahu dapat dilihat pada Tabel 2

Uji analisis instrumen penelitian ini adalah :

1. Uji validitas, untuk menilai sahih atau tidaknya sebuah instrumen penelitian dalam hal ini berupa kuesioner. Sahih dan tidaknya kuesioner apabila pertanyaan pada kuesioner dapat memberikan informasi tentang apa yang akan diukur pada kuesioner tersebut. Menurut Idrus (2009) kuesioner dikatakan sahih atau valid jika nilai korelasi $r$ hitung $>r$ tabel, artinya taraf probabilitas kesalahan $($ sig $) \leq 0,05$. Uji validitas pada penelitian ini menggunakan aplikasi SPSS.

2. Uji reliabilitas, kuesioner dinyatakan reliabel apabila mampu menjaga konsistensi jawaban dari responden dengan baik, artinya jika nilai alpha $(\alpha) \geq 0,6$ maka kuesioner dikatakan reliabel (Idrus 2009). Uji reliabilitas menggunakan alat bantu berupa aplikasi SPSS. 
Tabel 2 Data persepsi nelayan terhadap penggunaan LPG sebagai bahan bakar pada mesin perahu

\begin{tabular}{|c|c|c|}
\hline No & Jenis Data & Metode Pengumpulan Data \\
\hline 1 & $\begin{array}{l}\text { Bagimana pendapat nelayan terhadap } \\
\text { ketersediaan } L P G 3 \mathrm{~kg} \text { bagi nelayan }\end{array}$ & $\begin{array}{l}\text { Wawancara terstruktur dengan jawaban } \\
\text { berbentuk skala Likert, yaitu: (1) sangat } \\
\text { terbatas (2) terbatas (3) lancar dan (4) sangat } \\
\text { lancar }\end{array}$ \\
\hline 2 & $\begin{array}{l}\text { Bagimana pendapat nelayan terhadap lokasi } \\
\text { perolehan LPG } 3 \mathrm{~kg} \text { bagi nelayan }\end{array}$ & $\begin{array}{l}\text { Wawancara terstruktur dengan jawaban } \\
\text { berbentuk skala Likert, yaitu: (1) sangat jauh } \\
(>2.5 \mathrm{~km})(2) \text { jauh (antara } 1-2.5 \mathrm{~km}) \text { (3) } \\
\text { dekat }(500 \mathrm{~m}-1 \mathrm{~km}) \text { dan (4) sangat dekat (< } \\
500 \mathrm{~m})\end{array}$ \\
\hline 3 & $\begin{array}{l}\text { Bagimana pendapat nelayan terhadap harga } \\
\text { (LPG } 3 \mathrm{~kg} \text { bagi nelayan }\end{array}$ & $\begin{array}{l}\text { Wawancara terstruktur dengan jawaban } \\
\text { berbentuk skala Likert, yaitu: (1) sangat } \\
\text { mahal, (2) mahal, (3) murah, dan (4) sangat } \\
\text { Murah }\end{array}$ \\
\hline
\end{tabular}

$4 \quad$ Bagaimana pendapat nelayan terhadap luasan area kerja di atas perahu dengan menggunakan LPG sebagai bahan bakar

Wawancara terstruktur dengan jawaban berbentuk skala Likert, yaitu: (1) sangat sempit, (2) sempit, (3) leluasa, dan (4) sangat Leluasa

5 Bagaimana pendapat nelayan terhadap sosialisasi yang diberikan tentang penggunaan LPG sebagai bahan bakar mesin perahu $<5 \mathrm{GT}$

Wawancara terstruktur dengan jawaban berbentuk skala Likert, yaitu: (1) sangat Jarang, (2) Jarang, (3) sering, dan (4) sangat Sering

6 Bagimana pendapat nelayan terhadap faktor keamanan dan Keselamatan dalam penggunaan LPG sebagai bahan bakar

Wawancara terstruktur dengan jawaban berbentuk skala Likert, yaitu: (1)tidak baik, (2) kurang baik (3) baik, dan (4) sangat Baik

7 Bagimana pendapat nelayan terhadap kemudahan pemasangan instalasi LPG ke mesin perahu

Wawancara terstruktur dengan jawaban berbentuk skala Likert, yaitu: (1) sangat rumit, (2) rumit, (3) praktis, dan (4) sangat praktis

8 Bagimana pendapat nelayan terhadap biaya operasional penangkapan dengan menggunakan LPG sebagai bahan bakar

9 Bagimana pendapat nelayan terhadap kecepatan perahu dengan menggunakan LPG $3 \mathrm{~kg}$

Wawancara terstruktur dengan jawaban berbentuk skala Likert, yaitu: (1) lebih tinggi, (2) tinggi, (3) rendah, dan (4) sangat rendah

Wawancara terstruktur dengan jawaban berbentuk skala Likert, yaitu: (1) sangat lambat, (2) lambat, (3) cepat, dan (4) sangat cepat

10 Bagaimana pendapat nelayan terhadap laju konsumsi bahan bakar untuk mesin yang menggunakan LPG $3 \mathrm{~kg}$

Wawancara terstruktur dengan jawaban berbentuk skala Likert, yaitu: (1) sangat boros, (2) boros, (3) hemat, dan (4) sangat hemat

Analisis penelitian ini menggunakan analisis distribusi proporsi. Distribusi proporsi digunakan untuk mengetahui persentase dari data yang dihasilkan pada masing-masing variabel. Rumus yang digunakan sebagai berikut (Hasan 2012).

$$
P=\left(\frac{F}{n}\right) \times 100 \%
$$


Keterangan:

$P$ : Nilai persentase

$F$ : jumlah dari setiap jawaban yang dipilih

$n$ : jumlah Responden

Analisis indeks digunakan untuk mengetahui gambaran secara umum terhadap persepsi nelayan terhadap penggunaan LPG sebagai bahan bakar pada mesin perahu. Kriteria yang digunakan dalam menginterpretasikan hasil pada penelitan ini adalah dengan menggunakan kriteria tiga kotak (Ferdinand 2006) Penelitian ini menggunakan 4 alternatif jawaban pada kuesioner yang diajukan kepada responden, sehingga nilai jawaban terkecil adalah 1 dan terbesar adalah 4, maka untuk menghitung indeks persepsi dari jawaban responden dilakukan dengan rumus sebagai berikut:

Nilai Indeks $=\frac{((\% P 1 \times 1)+(\% P 2 x 2)+(\% P 3 \times 3)+(\% P 4 \times 4))}{N}$

Keterangan:

$P 1$ : prosentase jumlah jawaban pilihan 1

P2 : prosentase jumlah jawaban pilihan 2

$P 3$ : prosentase jumlah jawaban pilihan 3

$P 4$ : prosentase jumlah jawaban pilihan 4

$N$ : Jumlah skala jawaban

Hasil perhitungan yang dilakukan, maka diperoleh nilai indeks minimal sebesar 25 dan nilai indeks maksimal sebesar 100 dengan selang sebesar 75. Selanjutnya selang sebesar 75 tersebut dibagi 3 sehingga menghasilkan selang sebesar 25 yang akan digunakan sebagai dasar interpretasi. Berikut nilai indeks yang digunakan, yaitu :

Nilai indeks $25.00 \%-50.00 \%$ : rendah

Nilai indeks $50.01 \%-75.00 \%$ : sedang

Nilai indeks $75.01 \%-100.00 \%$ : tinggi

\section{HASIL DAN PEMBAHASAN}

\section{Karakteristik Sosial-Ekonomi Nelayan Kabupaten Sukabumi}

Responden pada penelitian ini adalah nelayan yang berlokasi di Kabupaten Sukabumi sebagai penerima paket bantuan konverter kit program konversi BBM ke LPG bagi nelayan dari Kementerian Energi dan Sumber Daya Mineral. Kuisioner yang dibagikan terdiri dari beberapa bagian yang menanyakan segala hal yang berkaitan dengan penggunaan LPG sebagai bahan bakar pada mesin perahu. Nelayan penerima paket konverter kit merupakan pengguna dari program konversi BBM ke LPG bagi nelayan yang bisa menginterpretasikan penggunaan LPG sebagai bahan bakar pada mesin perahu dengan jelas.

Tabel 3 Sebaran responden berdasarkan umur

\begin{tabular}{llcc}
\hline No & $\begin{array}{c}\text { Umur Responden } \\
(\text { Depkes RI 2009) }\end{array}$ & $\begin{array}{c}\text { Jumlah } \\
\text { responden }\end{array}$ & Prosentase (\%) \\
\hline 1. & Remaja : $12-25$ tahun & 1 & 1.064 \\
2. & Dewasa $: 26-45$ tahun & 60 & 63.830 \\
3. & Lansia : $46-56$ tahun & 31 & 32.979 \\
4. & Manula $:>56$ tahun & 2 & 2.128 \\
\hline
\end{tabular}

Berdasarkan Tabel 3 didapatkan bahwa nelayan penerima paket konverter kit berdasarkan karakteristik umur dari total responden sebanyak 94 orang nelayan sebagian besar berusia sekitar 26 
sampai 45 tahun atau pada rentang usia dewasa yaitu sebanyak 60 orang $(63.830 \%)$ dan pada rentang usia lansia (46-56 tahun) sebanyak 31 orang (32.979\%). Namun, terdapat pula nelayan yang masih berusia remaja sebanyak 1 orang (1. 064\%) dan nelayan dengan rentang usia manula ( $>56$ tahun) sebanyak 2 orang $(2.128 \%)$.

Tabel 4 Sebaran responden berdasarkan tingkat pendidikan

\begin{tabular}{clcc}
\hline No & \multicolumn{1}{c}{$\begin{array}{c}\text { Tingkat pendidikan } \\
\text { (UU No. 20/2009) }\end{array}$} & Jumlah respondes & Prosentase (\%) \\
\hline 1 & Tidak Lulus SD & 8 & 8.511 \\
2 & Lulus SD & 40 & 42.553 \\
3 & Lulus SLTP & 39 & 41.489 \\
4 & Lulus SLTA & 7 & 7.447 \\
\hline
\end{tabular}

Latar belakang pendidikan nelayan penerima bantuan paket konverter kit di Kabupaten Sukabumi seperti digambarkan pada Tabel 2 bahwa dari responden sebanyak 94 orang rata-rata memiliki jenjang pendidikan SD dan SMP dengan jumlah sebanyak 40 orang (42.533\%) merupakan lulusan pendidikan dasar dan 39 orang $(41.489 \%)$ merupakan lulusan sekolah menengah pertama. Sebanyak 8 orang $(8.511 \%)$ tidak lulus SD, dan hanya sebanyak 7 orang $(7.44 \%)$ yang dapat melanjutkan ke jenjang SLTA.

Tabel 5 Sebaran responden berdasarkan pengalaman

\begin{tabular}{clcc}
\hline No & Pengalaman & Jumlah responden & Prosentase (\%) \\
\hline 1 & Selama $0-12,5$ tahun & 34 & 36.170 \\
2 & Selama 12.6 - 25 tahun & 46 & 48.936 \\
3 & Selama 25,1 - 37.5 tahun & 11 & 11.702 \\
4 & Selama 37.6 - 50 tahun & 3 & 3.191 \\
\hline
\end{tabular}

Berdasarkan Tabel 5 pengalaman menjadi nelayan dari 94 responden nelayan penerima paket konverter kit memiliki pengalaman yang sudah relatif lama. sebanyak 46 orang (48.936\%) memiliki pengalaman di atas 13 tahun bahkan sebanyak 3 orang (3.191\%) memiliki pengalaman yang sudah diatas 40 tahun. Namun banyak juga nelayan yang masih berpengalaman dibawah 13 tahun yaitu sebanyak 34 orang $(36.170 \%)$.

Tabel 6 Sebaran responden yang mendapatkan sosialisasi

\begin{tabular}{clcc}
\hline No & \multicolumn{1}{c}{ Sosialisasi } & Jumlah responden & Prosentase (\%) \\
\hline 1 & Tidak pernah & 4 & 4.255 \\
2 & Pernah & 90 & 95.745 \\
\hline
\end{tabular}

Nelayan di Kabupaten Sukabumi sebagian besar pernah mengikuti sosialisasi yang terkait dengan perikanan yaitu dari 94 responden sebanyak 90 orang $(95.745 \%)$ pernah mengikuti sosialisasi. Hal ini menunjukan bahwa nelayan memiliki antusiasme yang tinggi terhadap informasi yang akan disampaikan. Namun, terdapat juga nelayan yang tidak pernah mengikuti sosialisasi yaitu sebanyak 4 orang atau sebesar $(4.255 \%)$.

Tabel 7 Sebaran responden berdasarkan pendapatan

\begin{tabular}{clcc}
\hline No & \multicolumn{1}{c}{ Pendapatan } & Jumlah responden & Prosentase (\%) \\
\hline 1 & di bawah UMK $(<2.583$ juta $)$ & 79 & 84.043 \\
2 & di atas UMK $(>2.583$ juta $)$ & 15 & 15.957 \\
\hline
\end{tabular}

Pendapatan nelayan penerima paket bantuan konverter kit dari sebanyak 94 orang yang diwawancarai memiliki pendapatan di bawah UMK Kabupaten Sukabumi yaitu sebanyak 79 orang atau 
sebesar (84.043\%) yaitu dikisaran Rp 1500000 sampai dengan Rp 2000 000. Namun ada juga yang memiliki pendapatan yang lebih besar dari UMK Kabupaten yakni sebanyak 15 orang (15.957\%) yaitu sebesar Rp 2. 600000.

\section{Persepsi Nelayan terhadap Penggunaan Bahan Bakar LPG pada Mesin Perahu}

Persepsi nelayan terhadap penggunaan LPG sebagai bahan bakar pada mesin perahu diukur dengan menggunakan instrumen yaitu kuesioner yang membantu untuk menanyakan penilaian 94 orang nelayan penerima bantuan paket konverter kit terhadap 10 (sepuluh) hal, meliputi : ketersediaan, harga, dan lokasi perolehan LPG, laju konsumsi bahan bakar LPG, biaya operasional, luasan area kerja, faktor keamanan dan keselamatan, kemudahan pemasangan instalasi konverter kit, kecepatan dan sosialisasi. Setelah kuisioner terkumpul maka langkah yang dilakukan adalah uji instrumen data penelitian yaitu :

\section{Uji Validitas}

Uji validitas dilakukan untuk menguji sejauh mana kuesioner yang digunakan valid atau tidak valid. Dasar pengambilan keputusannya adalah nilai $r$ hitung dibandingkan dengan nilai $r$ tabel atau nilai probabilitas ( $p$-value). Kuesioner dinyatakan valid bila koefisien korelasi (nilai $r$-hitung) $>$ r-tabel atau nilai $p$-value $<0.05$. Adapun $r$-tabel pada $\mathrm{n}=94$ adalah 0.2028 . Dengan demikian seluruh $\mathrm{r}-$ hitung (koefisien korelasi) yang diperoleh lebih besar dari r-tabel artinya kuesioner yang digunakan dinyatakan valid. Seperti ditunjukan pada Tabel 8.

Tabel 8 Hasil uji validitas variabel persepsi penggunaan bahan bakar LPG pada mesin perahu

\begin{tabular}{rlccc}
\hline No & \multicolumn{1}{c}{ Pernyataan } & r Hitung & r Tabel & Ket \\
\hline 1 & Ketersediaan LPG 3 kg & 0.5166 & 0.2028 & valid \\
2 & Lokasi perolehan LPG 3 kg & 0.7153 & 0.2028 & valid \\
3 & Harga LPG 3 kg & 0.7445 & 0.2028 & valid \\
4 & Luas area kerja di atas perahu & 0.2385 & 0.2028 & valid \\
5 & Sosialisasi mengenai konverter kit & 0.6329 & 0.2028 & valid \\
6 & Faktor keamanan dan keselamatan & 0.5772 & 0.2028 & valid \\
7 & Pemasangan instalasi konverter kit & 0.2280 & 0.2028 & valid \\
8 & Biaya operasional & 0.4871 & 0.2028 & valid \\
9 & Kecepatan perahu & 0.4650 & 0.2028 & valid \\
10 & Laju konsumsi bahan bakar & 0.6676 & 0.2028 & valid \\
\hline
\end{tabular}

\section{Uji Reliabilitas}

Uji reliabilitas dilakukan dengan menggunakan SPSS, kuesioner dinyatakan reliabel jika nilai cronbach alpha > 0.60 (Idrus 2009). Hasil penelitian berdasarkan seluruh konstruk/variabel yang diperoleh diketahui bahwa koefisien alpha sebesar 0.7185 lebih besar dari 0.60 artinya bahwa kuesioner yang digunakan dinyatakan reliabel.

Penggunaan LPG sebagai bahan bakar pada mesin perahu akan dipengaruhi oleh persepsi nelayan. Persepsi merupakan hasil kerja otak dalam memahami atau menilai suatu hal yang terjadi di sekitarnya (Waidi 2006). Setiap nelayan memiliki persepsi berbeda-beda Menurut Nababan (2017) persepsi seseorang akan berbeda antara satu dengan yang lain, karena setiap individu memiliki penafsiran yang berbeda-beda dari sesuatu yang diterimanya. Perbedaan tersebut bisa dipengaruhi oleh banyak faktor, diantaranya adalah karakteristik sosial-ekonomi.. Demikian juga dengan persepsi nelayan terhadap penggunaan bahan bakar LPG pada mesin perahu di Kabupaten Sukabumi, menunjukan hasil yang berbeda. Hasil penelitian menunjukan nilai indeks persepsi nelayan terhadap penggunaan LPG $3 \mathrm{~kg}$ sebagai bahan bakar berada pada kategori sedang sehingga perlu ditingkatkan. 
Tabel 9 Indeks persepsi nelayan terhadap penggunaan bahan bakar LPG pada mesin perahu

\begin{tabular}{|c|c|c|c|c|c|}
\hline No. & Persepsi & $\begin{array}{l}\text { Jumlah } \\
\text { responden } \\
\text { (Org) }\end{array}$ & $\begin{array}{l}\text { Sebaran } \\
\text { responden } \\
(\%)\end{array}$ & $\begin{array}{c}\text { Indeks } \\
\text { Persepsi } \\
(\%)\end{array}$ & Interpretasi \\
\hline \multirow[t]{5}{*}{1} & Ketersediaan LPG $3 \mathrm{~kg}$ & & & \multirow{5}{*}{46.28} & \multirow{5}{*}{ rendah } \\
\hline & sangat terbatas & 29 & 30.85 & & \\
\hline & terbatas & 50 & 53.19 & & \\
\hline & lancar & 15 & 15.96 & & \\
\hline & sangat lancar & 0 & 0.00 & & \\
\hline \multirow[t]{5}{*}{2} & Lokasi perolehan LPG 3 kg & & & \multirow{5}{*}{68.35} & \multirow{5}{*}{ sedang } \\
\hline & sangat jauh $(>2.5 \mathrm{~km})$ & 6 & 6.38 & & \\
\hline & jauh (antara $1 \mathrm{~km}-2.5 \mathrm{~km}$ ) & 33 & 35.11 & & \\
\hline & dekat $(500 \mathrm{~m}-1 \mathrm{~km})$ & 35 & 37.23 & & \\
\hline & sangat dekat $(<500 \mathrm{~m})$ & 20 & 21.28 & & \\
\hline \multirow[t]{5}{*}{3} & Harga LPG 3 kg & & & \multirow{5}{*}{67.02} & \multirow{5}{*}{ sedang } \\
\hline & sangat mahal & 0 & 0.00 & & \\
\hline & mahal & 37 & 39.36 & & \\
\hline & murah & 50 & 53.19 & & \\
\hline & sangat murah & 7 & 7.45 & & \\
\hline \multirow[t]{5}{*}{4} & Luasa area kerja & & & \multirow{5}{*}{37.23} & \multirow{5}{*}{ rendah } \\
\hline & sangat sempit & 48 & 51.06 & & \\
\hline & sempit & 46 & 48.94 & & \\
\hline & leluasa & 0 & 0.00 & & \\
\hline & sangat leluasa & 0 & 0.00 & & \\
\hline \multirow[t]{6}{*}{5} & Sosialisasi penggunaan & & & \multirow{6}{*}{42.55} & \multirow{6}{*}{ rendah } \\
\hline & LPG sebagai bahan bakar & & & & \\
\hline & sangat jarang & 38 & 40.43 & & \\
\hline & jarang & 46 & 48.94 & & \\
\hline & sering & 10 & 10.64 & & \\
\hline & sangat sering & 0 & 0.00 & & \\
\hline \multirow[t]{6}{*}{6} & Faktor keamanan dan & & & \multirow{6}{*}{39.89} & \multirow{6}{*}{ rendah } \\
\hline & keselamatan & & & & \\
\hline & tidak baik & 41 & 43.62 & & \\
\hline & kurang baik & 50 & 53.19 & & \\
\hline & baik & 3 & 3.19 & & \\
\hline & sangat baik & 0 & 0.00 & & \\
\hline \multirow[t]{6}{*}{7} & Pemasangan instalasi konverter & & & \multirow{6}{*}{43,88} & \multirow{6}{*}{ rendah } \\
\hline & kit & & & & \\
\hline & sangat rumit & 34 & 36,17 & & \\
\hline & rumit & 49 & 52.13 & & \\
\hline & praktis & 11 & 11.70 & & \\
\hline & sangat praktis & 0 & 0.00 & & \\
\hline \multirow[t]{5}{*}{8} & Biaya operasional & & & \multirow{5}{*}{78.46} & \\
\hline & sangat tinggi & 0 & 0.00 & & \\
\hline & tinggi & 11 & 11.70 & & tinggi \\
\hline & rendah & 59 & 62.77 & & \\
\hline & sangat rendah & 24 & 25.53 & & \\
\hline 9 & Kecepatan perahu & & & & \\
\hline & sangat lambat & 59 & 62.77 & 34,31 & rendah \\
\hline & lambat & 35 & 37.23 & & \\
\hline
\end{tabular}




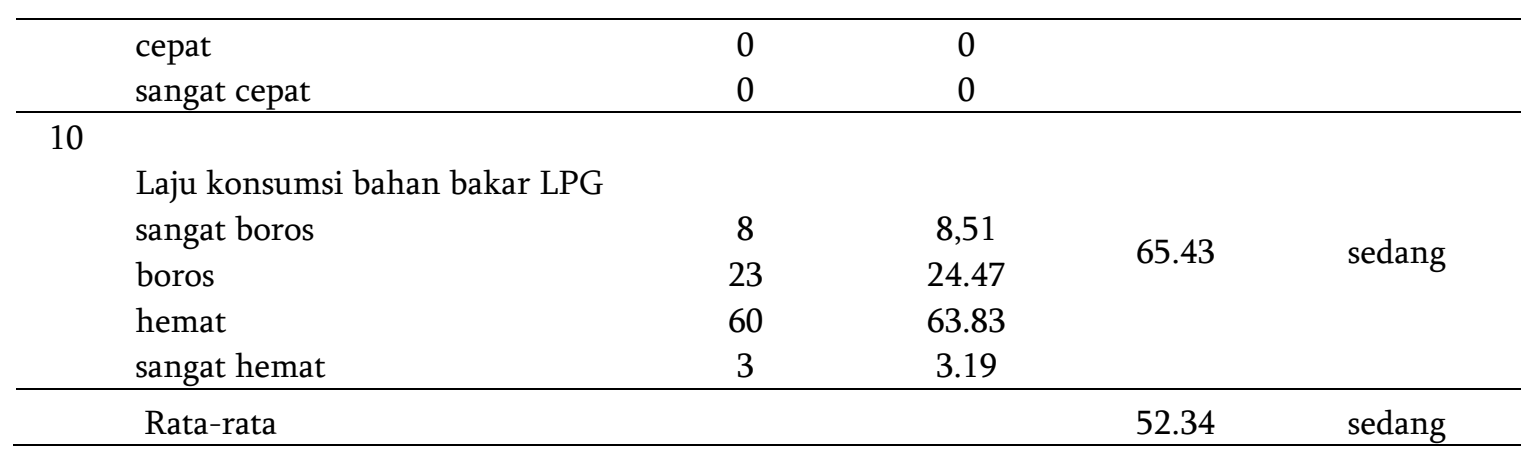

Berdasarkan Tabel 9, persepsi nelayan terhadap ketersediaan LPG $3 \mathrm{~kg}$ bagi nelayan terpusat pada kategori 1 (sangat terbatas) dan Kategori 2 (terbatas). Sebanyak 29 orang nelayan atau sebesar 30.85\% menilai bahwa ketersediaan LPG $3 \mathrm{~kg}$ sangat terbatas sedangkan sebanyak 50 orang nelayan atau sebesar 53.19\% menilai terbatas. Hal tersebut menunjukan bahwa ketersediaan LPG $3 \mathrm{~kg}$ masih sulit didapat, agen yang khusus menyediakan tabung LPG $3 \mathrm{~kg}$ untuk nelayan juga selalu tidak tersedia stoknya. Distribusi yang terbuka serta tidak adanya perbedaan kemasan antara tabung LPG $3 \mathrm{~kg}$ untuk nelayan dan untuk skala rumah tangga yang menyebabkan pendistribusian menjadi salah sasaran. Namun, di beberapa tempat ketersediaan LPG tergolong lancar dan mudah di dapat, hal tersebut dinilai oleh nelayan sebanyak 15 orang atau sebesar 15.96\%. Secara umum indeks persepsi ketersediaan LPG $3 \mathrm{~kg}$ bagi nelayan berada pada kategori rendah.

Lokasi perolehan LPG $3 \mathrm{~kg}$ bagi nelayan berdasarkan penilaian sebanyak 94 orang nelayan, sebanyak 6 orang atau sebesar 6.38\% menilai lokasi perolehan LPG $3 \mathrm{~kg}$ sangat jauh dan sebanyak 33 orang nelayan atau sebesar 35.11\% menilai jauh. Hal tersebut menunjukan bahwa lokasi agen atau pangkalan yang menyediakan LPG $3 \mathrm{~kg}$ bagi nelayan berada diluar tempat aktifitas nelayan. Namun sebanyak 35 orang atau 37.23\% menilai bahwa lokasi perolehan LPG $3 \mathrm{~kg}$ bagi nelayan menilai dekat bahkan sebanyak 20 orang atau sebesar $21.28 \%$ dinilai sangat dekat. Hal tersebut menunjukan bahwa agen/pangkalan yang menyediakan gas LPG $3 \mathrm{~kg}$ khusus bagi nelayan berada di lingkungan tempat nelayan beraktifitas. Indeks persepsinya berada dalam kategori sedang.

Harga LPG $3 \mathrm{~kg}$ menurut penilaian sebanyak 37 orang nelayan atau sebesar $39.36 \%$ menilai bahwa harga LPG $3 \mathrm{~kg}$ tergolong mahal. Sedangkan menurut penilaian sebanyak 50 orang nelayan atau sebesar 53.19\% menyatakan bahwa harga gas LPG $3 \mathrm{~kg}$ termasuk kategori murah dan sebanyak 7 orang nelayan atau sebesar 7.45\% menilai sangat murah. Harga jual eceran untuk LPG $3 \mathrm{~kg}$ khususnya untuk nelayan telah ditetapkan sebesar Rp12.750,00 (ESDM 2016), namun di agen atau distributor gas LPG $3 \mathrm{~kg}$ berada di kisaran harga sebesar Rp17.000,00 sampai Rp18.000,00. Harga tersebut dianggap murah bahkan sangat murah dibandingkan dengan harga gas LPG $3 \mathrm{~kg}$ untuk umum atau yang dijual di warung-warung yang memiliki kisaran harga Rp20.000,00 sampai Rp23.000,00, sehingga secara umum persepsi nelayan terhadap harga LPG $3 \mathrm{~kg}$ berada dalam kategori sedang.

Berdasarkan penilaian sebanyak 94 orang nelayan terhadap persepsi luasan area kerja di atas perahu dengan menggunakan gas LPG $3 \mathrm{~kg}$ sebagai bahan bakar, menurut 48 orang nelayan atau sebesar 51.06\% adanya muatan tambahan berupa 2 buah tabung LPG $3 \mathrm{~kg}$ di atas perahu menjadi menyebabkan luasan area kerja untuk aktifitas penangkapan menjadi lebih sempit dan sebanyak 46 atau sebesar $96.83 \%$ berpendapat sempit. Sehingga indeks persepsi nelayan terhadap luasan area kerja diatas kapal berada dalam kategori rendah yaitu sebesar $37.23 \%$.

Peran pemerintah dalam hal sosialisasi mengenai penggunaan LPG $3 \mathrm{~kg}$ sebagai bahan bakar alternatif dinilai oleh 38 orang nelayan atau sebesar $40.43 \%$ sangat jarang dan 46 orang nelayan atau sebesar $48.94 \%$ menilai jarang. Sehingga persepsi nelayan terhadap peranan pemerintah dalam hal sosialisasi penggunaan LPG $3 \mathrm{~kg}$ sebagai bahan bakar pada mesin perahu berada dalam kategori rendah. Namun, ada sebanyak 10 orang nelayan atau sebesar $10,64 \%$ yang menilai sosialisasi mengenai penggunaan LPG sebagai bahan bakar alternatif sering dilakukan oleh pemerintah. 
Aspek keamanan dinilai oleh 41 nelayan atau sebesar 43,63\% tidak baik dan sebanyak 50 nelayan atau sebesar 53,19\% menilai kurang baik. Hal ini sesuai dengan penelitian Vikalista (2012) bahwa persepsi negatif nelayan terhadap penggunaan LPG dipengaruhi oleh informasi-informasi tentang banyaknya kejadian ledakan pada gas LPG $3 \mathrm{~kg}$ pada skala rumah tangga. Penilaian yang berbeda diberikan oleh 3 orang nelayan atau sebesar 3,19\% yang menilai aspek keamanan pada gas LPG 3 kg sudah baik. Indeks persepsi nelayan pada variabel faktor keamanan dan keselamatan penggunaan LPG sebagai bahan bakar pada mesin perahu bernilai 39,89\% termasuk kategori rendah.

Pemasangan instalasi konverter kit pada mesin perahu oleh 34 orang nelayan $(36,17 \%)$ dinilai sangat rumit dan oleh 49 nelayan (52,19\%) dinilai rumit. Hal ini menunjukan bahwa penggunaan LPG pada mesin perahu mempunyai perangkat yang sulit dipahami oleh nelayan dalam arti tidak praktis. Nelayan diharuskan merangkai dan memasang terlebih dahulu komponen konverter kit pada mesin perahu, dan memasangkan regulator pada tabung. Pemasangan regulator yang kurang tepat atau tidak cocok dengan tabung yang digunakan sehingga dapat memicu kebocoran, hal inilah yang membuat nelayan kesulitan dalam pemanfaatan LPG sebagai bahan bakar pada mesin perahu. Namun sebagian nelayan yaitu sebanyak 10 orang atau sebesar 10,64\% menilai pemasangan instalasi konverter kit sudah praktis dalam arti dengan mudah dapat rangkai oleh nelayan. Indeks persepsi nelayan pada variabel pemasangan instalasi konverter kit bernilai 43,88\% termasuk kategori rendah.

Biaya operasional dengan menggunakan LPG $3 \mathrm{~kg}$ sebagai bahan bakar pada mesin perahu dinilai oleh 11 orang nelayan (11,70\%) dikategori tinggi. Sedangkan sebanyak 59 orang nelayan $(62,77 \%)$ menilai rendah bahkan sebanyak 24 orang nelayan atau sebesar 25,53\% menilai sangat rendah. Hal ini sesuai dengan penelitian yang dilakukan Baruno, et al. (2014) bahwa biaya operasional penggunaan LPG pada mesin perahu menjadi lebih efisien yaitu sebanyak $41,76 \%$ dibandingkan biaya yang dikeluarkan apabila menggunakan bahan bakar minyak (premium). Indeks persepsi nelayan terhadap biaya operasional dengan menggunakan LPG sebagai bahan bakar pada mesin perahu termasuk kategori tinggi dengan nilai 78,46\%.

Faktor teknis yang ditanyakan kepada 94 orang nelayan adalah kecepatan perahu. Kecepatan perahu berbahan bakar gas LPG $3 \mathrm{~kg}$ dibandingkan dengan bahan bakar minyak menurut pendapat 59 orang nelayan (62,77\%) menilai sangat lambat dan 35 orang nelayan (37,23\%) yang menilai lambat. $\mathrm{Hal}$ ini sesuai dengan pernyataan Indartono (2012) bahwa kelemahan penggunaan gas LPG $3 \mathrm{~kg}$ pada mesin motor adalah daya dorong (power) yang lemah apabila dibandingkan dengan mesin motor menggunakan bahan bakar minyak. Nilai indeks persepsi sebesar 34,31\% termasuk kategori rendah.

Laju konsumsi bahan bakar dinilai oleh sebanyak 8 orang nelayan $(8,51 \%)$ penggunaan gas LPG $3 \mathrm{~kg}$ pada mesin perahu menjadi sangat boros dan sebanyak 23 orang nelayan $(24,47 \%)$ menilai boros. Namun sebanyak 60 orang nelayan atau sebesar 63,83\% menilai laju konsumsi bahan bakar dengan menggunakan gas LPG $3 \mathrm{~kg}$ menjadi hemat bahkan sebanyak 3 orang nelayan (3,19\%) menilai sangat hemat. Hal ini sesuai dengan penelitian yang dilakukan oleh Baruno, et al. (2014) bahwa konsumsi bahan bakar menggunakan LPG pada mesin perahu akan menjadi lebih hemat sebanyak 26,35\% dibandingkan menggunakan bahan bakar minyak (premium). Nilai indeks persepsi sebesar 65,43\% dengan kategori sedang.

\section{KESIMPULAN DAN SARAN}

Nelayan kecil di Kabupaten Sukabumi sebagian besar berusia produktif, memiliki pengalaman yang relatif lama, dan aktif mengikuti sosialisasi terkait perikanan. Namun disisi lain, nelayan umumnya memiliki tingkat pendidikan sampai sekolah dasar dan sekolah tingkat pertama, dan memiliki pendapatan rata-rata di bawah upah minimum kabupaten. Indeks persepsi nelayan terhadap penggunaan LPG pada mesin perahu secara umum memiliki nilai sebesar 52,34\% termasuk kategori sedang. 
Adapun saran dari penelitian adalah perlu adanya pendampingan dan pelatihan berkala oleh Dinas Kelautan dan Perikanan Kabupaten Sukabumi dalam rangka meningkatkan pemahaman nelayan terhadap penggunaan LPG sebagai bahan bakar pada mesin perahu. Perbaikan pada perangkat konverter kit berupa jaminan keamanan produk yang tinggi berdasarkan Standar Nasional Indonesia (SNI), ketersediaan LPG yang selalu terjamin, serta lokasi perolehan LPG dekat dengan aktifitas nelayan.

\section{DAFTAR PUSTAKA}

Baruno B, Iskandar BH, Imron M, Mawardi W. 2014. Kinerja LPG pada Motor Bakar 6,5 HP Sebagai Bahan Bakar Alternatif Perahu Penangkap Ikan. Marine Fisheries. 5(1) : 13-25.

[DKP Kabupaten Sukabumi] Dinas Kelautan dan Perikanan Kabupaten Sukabumi. 2018. Laporan Tahunan 2017. Sukabumi.

Ferdinand. 2006. Metode Penelitian Manajemen: Pedoman Penelitian untuk skripsi, Tesis dan Disertai Ilmu Manajemen. Semarang (ID): Universitas Diponegoro.

Hasan I. 2012. Pokok-Pokok Materi Statistik 2 (Statistik Inferensif). Jakarta (ID): PT.Bumi Aksara.

Idrus M. 2009. Metode Penelitian Ilmu Sosial. Jakarta (ID) : Erlangga.

Indartono. 2012. Pemakaian Bahan Bakar Gas menjadi Alternatif bagi Kendaraan Bermotor Berbahan Bakar Premium. Gema Teknologi. 1 (17) : 18-21.

[KESDM] Kementerian Energi dan Sumber Daya Mineral. 2016. Keputusan Menteri Energi dan Sumber Daya Mineral Nomor 7436K/12/MEM/2016 tentang Harga Jual Eceran Liquefied Petroleum Gas Tabung 3 Kilogram untuk Keperluan Kapal Perikanan bagi Nelayan Kecil. Jakarta (ID) : KESDM.

[KESDM] Kementerian Energi dan Sumber Daya Mineral. 2017. Capaian Pembangunan Tahun 2016 Direktorat Jenderal Minyak dan Gas Bumi. Jakarta (ID) : KESDM.

[KESDM] Kementerian Energi dan Sumber Daya Mineral. 2018. Capaian Pembangunan Tahun 2017 Direktorat Jenderal Minyak dan Gas Bumi. Jakarta (ID) : KESDM.

Kuncoro A, Mamuri, Wasis S, Wisnugroho S. 2016. LPG sebagai Energi Alternatif untuk Bahan Bakar Dual-Fuel Mesin Diesel Kapal Nelayan Tradisional. Seminar Nasional Sains dan Teknologi 2016. 8 November 2016 Fakultas Teknik Universitas Muhammadiyah Jakarta (ID) : 1-12.

Mulyatno IP, Sisworo SJ, Panuntun DS. 2013. Kajian Teknis dan Ekonomis Penggunaan Dual-fuel System (LPG-Solar) pada Mesin Diesel Kapal Nelayan Tradisional. Jurnal Teknis Perkapalan : 10 (2) : 98-107.

Nababan B, Wiyono ES, Mustaruddin. 2017. Persepsi dan Kepatuhan Nelayan Tanjung Balai Asahan Sumatera Utara dalam Mendukung Perikanan Tangkap yang Berkelanjutan. Marine Fisheries. $8(2): 163-174$.

Nono FGB, Yudo H, Budiarto U. 2017. Studi Perbandingan Mesin Outboard Honda GX200 Bahan Bakar Bensin Premium dan Bahan Bakar Elpiji yang Dimodifikasi dengan Konverter Gas pada Kapal Nelayan Tradisional Tanjung Mas. Jurnal Teknis Perkapalan 1 (5) : 223-236.

Sugiyono. 2013. Metode Penelitian Kombinasi (Mixed Methods). Bandung (ID): Penerbit Alfabeta.

Vikalista E. 2012. Implementasi Kebijakan Konversi Minyak Tanah ke LPG (Liquified Petroleum Gas) di Kecamatan Banjarmasin Utara Kota Banjarmasin. Jurnal ilmu Politik dan Pemerintahan Lokal. 2 (1): 40-57.

Waidi. 2006. The Art of Re-engineering Your Mind for Success. Jakarta (ID): Gramedia. 
Wibowo S. 2016. Peralihan BBM ke BBG Tingkatkan Ekonomi Nelayan [internet]. [diakses 2018 Februari 8]. Tersedia dari : https://ekbis.sindonews. com/read/1142754/77/peralihan-bbm-kebbg-tingkatkan-ekonomi-nelayan-147498560. 